\title{
The Effect of Investigation Multiliteracy Method and Prior Ability on Learning Outcomes of Constructing Explanatory Texts Among Eleventh-Grade Students at SMA Posigadan State Senior High School
}

\author{
Sayama Malabar ${ }^{1}$ (ID $\triangle$ and Meilina Widya Dali ${ }^{2}$ S(D) \\ ${ }^{12}$ Study Program of Indonesian Language Education, Faculty of Letters and Culture, Universitas Negeri Gorontalo \\ $\triangle$ Corresponding Author: Sayama Malabar, E-mail: sayama.malabar1@gmail.com
}

\section{ARTICLE INFORMATION ABSTRACT}

Received: April 11, 2021

Accepted: May 17, 2021

Volume: 3

Issue: 5

DOI: $10.32996 /$ jhsss.2021.3.5.2

\section{KEYWORDS}

Effect, investigation multiliteracy, prior ability, learning outcomes, constructing explanatory texts
This study aims to describe the learning outcomes of constructing explanatory texts among eleventh-grade students taught by investigating the multiliteracy and conventional methods, the difference in learning outcomes of students taught by investigating the multiliteracy and conventional methods for those with a high and low prior ability, and the effect of investigation multiliteracy method and prior ability on learning outcomes in SMA Posigadan state senior high school. Furthermore, an experimental method was employed with a $2 \times 2$ factorial design. It was shown that (1) students taught by the investigation multiliteracy method got higher learning outcomes (an average score of 79) than those who studied using a conventional method with an average score of 62.81. (2) the average learning outcome of students with the high prior ability and taught by the investigation multiliteracy arrived at 78; no major difference from those with the high prior ability and relying on a conventional method (an average learning outcome of 75). Likewise, the average learning outcome of students with the low prior ability and taught by the investigation multiliteracy reached 52.81; no major difference from those with the low prior ability and studying with a conventional method (an average learning outcome of 46.94). (3) the p-value in the interaction between the investigation multiliteracy method and prior ability got 0.007 or less than $\alpha=5 \%$. Thus, $\mathrm{H} 0$ was rejected and accepted $\mathrm{H} 1$, meaning that the investigation multiliteracy method and prior ability influence students' learning outcomes.

\section{Introduction}

Learning is an interaction between students, teachers, and learning resources in an educational environment. Teachers develop the learning process to improve students' creative thinking and the ability to construct new knowledge as an effort to better learning topic mastery. According to Arifin (2010), the learning process is a systematic and systemic activity that is interactive and communicative between teachers, students, learning resources, and the environment to create classroom learning.

If the students are actively engaged in the learning process, even discover and construct their own knowledge, the outcomes will be more satisfying. This is due to the fact that what is found by students themselves will remain in their memory. Teachers do not need to require the students to memorize as they will automatically remember what has been learned. For this reason, it is essential to employ a method that can involve and engage students to learn, develop their thinking ability to discover knowledge personally, as well as correctly understand the learning concept. By this, the learning process becomes enjoyable.

In Indonesian Language learning, students must master four skills: listening, speaking, reading, and writing. They are inextricably linked and complement each other, as teachers and students interact during the learning process in order to achieve the determined basic competencies.

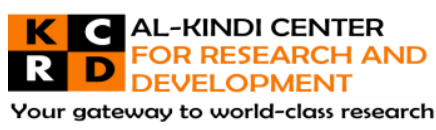

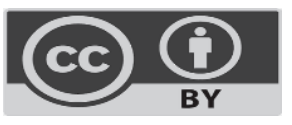

Published by Al-Kindi Center for Research and Development. Copyright (c) the author(s). This open access article is distributed under a Creative Commons Attribution (CC-BY) 4.0 license 
One of the basic competencies of eleventh-grade students that also serves as this research object is basic competence 4.3: constructing information (knowledge and series of events) in explanatory texts in writing or orally (Kemendikbud, 2017). Students are expected to collect information in an explanatory text, reconstruct the text based on its structure, and present the explanatory text.

The observation and interview with Indonesian Language teachers of eleventh graders in SMA Posigadan, South Bolaang Mongondow Regency show that $50 \%$ of students find it hard to construct explanatory texts. When the teacher directs the students to construct this text, it is difficult for them to reconstruct its structure based on the series of events. Besides, they pay less attention to the cohesiveness between paragraphs, sentence structures, spelling, and punctuation.

The above issue is generally related to teachers' role in the learning process, in which they are yet to rely on a creative method. Slameto (2010) opines that teaching methods can be applied in the teaching process. Teaching methods being used should motivate students to involve in the lesson actively. Nevertheless, a conventional method (lecture) dominates classroom learning, so that teachers make students an object and lead to one-way communication. In addition, students become indolent, less creative, less critical, and less enthusiastic in responding to something. They also have fewer opportunities to discover or construct knowledge by themselves; instead, they accept the information from books or teachers.

If the students get engaged actively with the learning process, even discover and construct their own knowledge, the outcomes will be more satisfying. This is because what is found by students themselves will remain in their memory. Teachers do not need to require the students to memorize as they will automatically remember what has been learned. For this reason, it is essential to employ a method that can involve and engage students to learn, develop their thinking ability to discover knowledge personally, as well as correctly understand the learning concept. By this, the learning process becomes enjoyable.

Regarding the issue mentioned above, the investigation multiliteracy method is applied. The method can improve reading multiliteracies (especially if the data source is documentation), writing data, and speaking. The term 'investigation' refers to any activities to investigate various data sources, including location, event, and documentation (Abidin, 2015). Investigation multiliteracy is able to enhance students' comprehension of learning materials as they actively participate during the investigation process.

Another factor to be concerned about during the learning process is students' prior ability. Prior ability plays a vital role in the effectiveness of a learning process since it depicts students' readiness to absorb the delivered topic. Uno (2010) points out that prior ability refers to learning outcomes gained before achieving high capability. At the beginning of the teaching process, teachers should recognize students' prior ability to lead them to plan and implement the learning process. The expected learning outcomes are thus acquired.

Explanatory texts inform us of a procedure or process of an event. Readers can have a clear and logical understanding of why something happens. The texts use facts and statements in connection with causality (Kosasi, 2014). Next, Restuti (2013) notes that explanatory texts describe or explain the process of a natural or social phenomenon.

Drawing from experts' ideas discussed earlier, explanatory texts explain how a natural or social phenomenon takes place. Such texts contain causality to explain a phenomenon observed in real life, e.g., tsunami. Despite this, it is quite challenging for students to grasp the concept of constructing explanatory texts to identify a phenomenon, describe the series of events, interpret or review the phenomenon that occurs. It is because they only memorize, not personally discover, the phenomenon going on in their neighbourhood. By relying on the investigation multiliteracy method, it is expected that students can play an active role during the lesson of constructing explanatory texts.

The following problems then need to be addressed (1) how do learning outcomes construct explanatory texts among students taught by the investigation multiliteracy method and a conventional method?; (2) how do learning outcomes of constructing explanatory texts among students taught by the investigation multiliteracy method differ from the ones taught by a conventional method, specifically those with high and low prior abilities?; (3) how do investigation multiliteracy and prior ability influence learning outcomes of constructing explanatory texts among eleventh-grade students in SMA Posigadan?

On this ground, this study aims to describe the learning outcomes of constructing explanatory texts among students taught by investigation multiliteracy and conventional methods, the difference in learning outcomes of students taught by investigation multiliteracy and conventional methods for those with a high and low prior ability, and the effect of investigation multiliteracy method and prior ability on learning outcomes of constructing explanatory texts among eleventh-grade students in the site area. 


\section{Methodology}

This research was conducted in SMA Posigadan, South Bolaang Mongondow Regency, because the researcher is a teacher in this school. It was conducted from January to February 2020, in the academic year of 2019/2020. An experimental method was used with a $2 \times 2$ factorial design and a manipulated variable (investigation multiliteracy method) and an attribute variable (prior ability). The research design is presented in the following Table 1.

Tabel 1. Research Design

\begin{tabular}{ccc}
\hline$A$ & \multicolumn{2}{c}{$B$} \\
\cline { 2 - 3 } & $\mathbf{B}^{1}$ & $\mathbf{B}^{\mathbf{2}}$ \\
\hline $\mathbf{A}^{1}$ & $\mathbf{A}^{1} \mathbf{B}^{1}$ & $\mathbf{A}^{\mathbf{1}} \mathbf{B}^{2}$ \\
$\mathbf{A}^{\mathbf{2}}$ & $\mathbf{A}^{\mathbf{2}} \mathbf{B}^{1}$ & $\mathbf{A}^{\mathbf{2}} \mathbf{B}^{\mathbf{2}}$ \\
\hline
\end{tabular}

Description:
A
$=$ Learning methods
$\mathrm{A}_{1} \quad=$ Investigation multiliteracy method
$\mathrm{A}_{2} \quad=$ Conventional method
B $\quad=$ Prior ability
$\mathrm{B}_{1} \quad=$ High prior ability
$\mathrm{B}_{2} \quad=$ Low prior ability
$\mathrm{A}_{1} \mathrm{~B}_{1} \quad=$ the average learning outcomes of constructing explanatory texts among eleventh-grade students in SMA Posigadan with high prior ability and taught by investigation multiliteracy method.
$A_{2} B_{1} \quad=$ the average learning outcomes of constructing explanatory texts among eleventh-grade students
$A_{2} B_{1} \quad=$ the average learning outcomes of constructing explanatory texts among eleventh-grade students in SMA Posigadan with high prior ability and taught by conventional method
$A_{1} B_{2} \quad=$ the average learning outcomes of constructing explanatory texts among eleventh-grade students in SMA Posigadan with low prior ability and taught by investigation multiliteracy method
$\mathrm{A}_{2} \mathrm{~B}_{2} \quad=$ the average learning outcomes of constructing explanatory texts among eleventh-grade students in SMA
Posigadan with low prior ability and taught by conventional method

The present study is comprised of independent and dependent variables. The independent variables included manipulated variables (investigation multiliteracy or $A_{1}$ and conventional method or $A_{2}$ ) and attribute variables (high prior ability or $B_{1}$ and low prior ability or $B_{2}$ ). Meanwhile, the dependent variable was the learning outcomes of constructing explanatory texts.

As many as 70 eleventh-grade students within three classes in the site area were involved as the population. Random sampling was carried out to select experimental class 1 and experimental class 2, assuming that the population was homogeneous because the class distribution was not based on students' achievement or rank. The selected samples were 21 students in XI MIA class and 21 students in XI IIS class. Research procedures encompassed preparation, implementation, and evaluation, as elaborated below.

\subsection{Research Procedures \\ 2.1.1 Preparation}

The steps in this stage consisted of: (1) Observing the school and consulting with Indonesian Language teachers of eleventh grade regarding the selected classes, research time, and materials being examined; (2) Requesting permit from relevant agencies in connection with the practice of this research; (3) Arranging the lesson plan for every meeting of the experimental class; (4) Arranging implementation plan and assessment rubric towards the outcomes of constructing explanatory texts; (5) Validating the lesson plan, student worksheet, and research instruments.

\subsubsection{Implementation}

The steps in this stage consisted of: (1) Identifying students' prior ability by using a prior ability test to find out the number of students with high and low prior abilities, as well as to determine whether or not the prior ability of the students in experimental and control classes were averagely the same; (2) Implementing the learning process in each class selected as the sample. The experimental class was taught by the investigation multiliteracy method, and the control class relied on the conventional method; it was performed according to the learning steps of each method; (3) Providing a post-test of explanatory text construction to the students in both experimental and control classes after the learning process in order to identify students' learning outcomes after treatment. 


\subsubsection{Evaluation}

The steps in this stage consisted of: (1) Processing the data of students' prior ability test results under the determined category;

(2) Processing, analyzing, and interpreting the data of explanatory text construction test results to discover the effect of the applied learning method and prior ability.

\subsection{Data Collection Techniques}

The data were collected from observation, prior ability test, and test, in which observation was done directly in the field. The researchers came to the research area and observed the teaching and learning activity in the classes to be examined. However, this technique was carried out during a pre-research. Students' prior ability is knowledge and skills possessed by the students before the learning process and depicts their readiness in learning next materials. Analyzing prior ability is a crucial step in developing the lesson. A multiple-choice test was utilized to identity such prior ability. On top of that, measuring students' understanding and skills required a test in the form of product.

\subsection{Data Analysis Techniques}

The collected data were analyzed using descriptive and inferential statistics. A descriptive statistical analysis was to describe the learning outcomes (score) of constructing explanatory texts of students in the experimental class, including mean, median, standard deviation, variance, range, maximum and minimum score.

Moreover, the data analysis was processed with SPSS 20 for Windows as the statistical analysis software. The learning outcomes of the explanatory text construction test before being analyzed through the software mentioned above was determined following assessment criteria that were adapted from the determination of learning outcomes by Arikunto (2011), as follows:

$$
\text { Score }=\frac{\text { obtained score }}{\text { maximum score }} \times 100
$$

Inferential statistical analysis was to test the validity of the proposed hypotheses. Before doing this analysis, analysis prerequisite tests, including data normality and homogeneity tests, were performed with the assistance of SPSS 20 for Windows.

\subsubsection{Normality Test}

The normality test was calculated using the One-Sample-Kolmogorov-Smirnov Test analysis with the assistance of SPSS 20 software. The tested hypotheses were as follows.

$\mathrm{H}_{0} \quad$ : Data were normally distributed

$\mathrm{H}_{1} \quad$ : Data were not normally distributed

The testing criterion was rejecting $\mathrm{H}_{0}$ if the sig. value or $\mathrm{p}$-value $<\alpha=5 \%$. Presented in the following table is the result of the normality test.

Table 2. Result of Data Normality Test of Learning Outcomes Based on Learning Methods

\begin{tabular}{llll}
\hline & & \multicolumn{2}{c}{ Learning Outcomes } \\
\cline { 3 - 4 } & & \multicolumn{2}{c}{$\begin{array}{c}\text { Investigation Multiliteracy } \\
\text { Method }\end{array}$} \\
\hline \multirow{3}{*}{ Kolmogorov-Smirnov } & Statistic & 0.121 & 0.161 \\
& Df & 21 & 21 \\
& sig. & 0.200 & 0.164 \\
\hline
\end{tabular}

Source: SPSS 20 output

The above table illustrates that the sig. Value or p-value of students' learning outcomes taught by investigation multiliteracy and conventional methods are 0.200 and 0.164 , respectively. Alternatively stated, the $\mathrm{p}$-value $>\alpha=5 \%$ or accepts $\mathrm{H}_{0}$, indicating that the data of students' learning outcomes taught by investigation multiliteracy and conventional methods have been normally distributed. Therefore, the normality assumption is fulfilled.

After testing the data normality of learning outcomes based on learning methods, the data normality of learning outcomes following students' prior ability was done. Given in the following table is the result of the normality test. 
Table 3. Result of Data Normality Test of Prior Ability

Prior Ability

\begin{tabular}{ccc} 
Kolmogorov- & statistic & 0.104 \\
Smirnov & df & 42 \\
& sig. & 0.200 \\
\hline
\end{tabular}

Source: SPSS 20 output

Table 3 shows that the sig. value or $p$-value of students' prior ability gets 0.200 . Simply put, the $p$-value $>\alpha=5 \%$ or accepts $H_{0}$, implying that students' data of learning outcomes with high and low prior abilities have been normally distributed. Therefore, the normality assumption is met.

\subsubsection{Homogeneity Test}

The homogeneity test of students' learning outcomes data was carried out with the assistance of SPSS 20 with the Levene Test of Equality of Error Variance analysis. The tested hypotheses were as follows.

$\mathrm{H}_{0} \quad$ : Data had the same variance (homogeneous)

$\mathrm{H}_{1} \quad$ : Data did not have the same variance (inhomogeneous)

The testing criterion was rejecting $\mathrm{H}_{0}$ if the sig. value or $p$-value $<\alpha=5 \%$. Provided in the following table is the result of the homogeneity test.

Table 4. Result of Data Homogeneity Test of Learning Outcomes of Constructing Explanatory Texts

\begin{tabular}{l|l|l|l|l}
\hline & $\mathrm{F}$ & $\mathrm{df1}$ & $\mathrm{df2}$ & Sig. \\
\hline Learning Outcomes & 0.866 & 3 & 38 & 0.467 \\
\hline
\end{tabular}

Source: SPSS 20 output

The above table displays that the sig. Value or $p$-value of students' learning outcomes is 0.467 . In other words, the $p$-value $>\alpha=$ $5 \%$ or accepts $\mathrm{H}_{0}$, implying that the data of students' learning outcomes have the same variance (homogeneous). Accordingly, the homogeneity assumption is met.

Since the normality and homogeneity assumptions had been fulfilled, the analysis was continued to inferential statistics, i.e., hypothesis testing applying the two-way analysis of variance.

\subsubsection{Gain Factor Test}

Table 5. The Result of Gain Factor Test

\begin{tabular}{|c|c|c|c|c|c|c|}
\hline \multirow{3}{*}{ Categories } & \multicolumn{6}{|c|}{ Learning Methods } \\
\hline & \multicolumn{2}{|c|}{ Investigation Multiliteracy } & \multirow{2}{*}{ Total } & \multicolumn{2}{|c|}{ Conventional } & \multirow{2}{*}{ Total } \\
\hline & B1 & $\mathrm{B} 2$ & & B1 & $\mathrm{B} 2$ & \\
\hline High & $0(0 \%)$ & $3(14 \%)$ & $14 \%$ & $0(0 \%)$ & $1(5 \%)$ & $5 \%$ \\
\hline Moderate & $1(5 \%)$ & 12 (57\%) & $62 \%$ & 1 (5\%) & $5(24 \%)$ & $29 \%$ \\
\hline Low & $4(19 \%)$ & $1(5 \%)$ & $24 \%$ & $2(10 \%)$ & $12(57 \%)$ & $67 \%$ \\
\hline Sum & $5(24 \%)$ & $16(76 \%)$ & $100 \%$ & $3(14 \%)$ & $18(86 \%)$ & $100 \%$ \\
\hline
\end{tabular}

Source: Appendix 7

Description:

B1 = High prior ability

B2 = Low prior ability

The above table shows the N-Gain score of students' learning outcomes in each learning method based on prior ability. In a class with the investigation multiliteracy method, no students with high prior ability are included in the high category, $5 \%$ of the students in the moderate category, and $19 \%$ in the low category. Meanwhile, $14 \%$ of students with low prior ability are included in the high category, $57 \%$ in the moderate category, and $5 \%$ in the low category. On this ground, the increase in students' learning outcomes with the low prior ability is higher than that of students with the high prior ability. In contrast, in a class 
employing a conventional learning method, no students with high prior ability are included in the high category, $5 \%$ of the students in the moderate category, and $10 \%$ in the low category. Next, $5 \%$ of students with low prior ability are included in the high category, $24 \%$ in the moderate category, and $57 \%$ in the low category. Hence, the increase in learning outcomes of students with low prior ability is higher than that of students with high prior ability. On the whole, students with the high prior ability and taught by the investigation multiliteracy method get higher learning outcomes than those taught by a conventional method. Students with a low prior ability and taught by a conventional method have higher learning outcomes than those taught by the investigation multiliteracy method.

\subsubsection{Hypothesis Test}

The results of the statistical test for hypotheses I and III using two-way analysis of variance are given in Table 6 below.

Table 6. The Result of Hypothesis Testing with Two-Way Analysis of Variance

\begin{tabular}{llllll}
\hline Source & $\begin{array}{l}\text { Sum of } \\
\text { Squares }\end{array}$ & Df & $\begin{array}{l}\text { Mean } \\
\text { Square }\end{array}$ & F & $\begin{array}{l}\text { p- } \\
\text { value }\end{array}$ \\
\hline Model & 214752.69 & 4 & 53688.17 & 529.45 & 0.000 \\
Learning & 457.40 & 1 & 457.40 & 4.51 & 0.040 \\
$\begin{array}{l}\text { Methods } \\
\text { IM }\end{array}$ & 821.16 & 1 & 821.16 & 8.10 & 0.007 \\
Method* & & & & & \\
Ability & & & & & \\
Error & 3853.31 & 38 & 101.40 & & \\
Total & 218606 & 42 & & & \\
\hline Source: SPSS 20 Output & & & &
\end{tabular}

Research hypotheses were tested through the two-way analysis of variance assisted by SPSS 20 . The testing criterion was rejecting $\mathrm{H}_{0}$ if the sig. value or $p$-value was less than $\alpha=5 \%$. Table 4.12 reveals that the model simultaneously gives a significant effect, as seen in the $p$-value of 0.000 or less than $\alpha=5 \%$. Thus, $\mathrm{H}_{0}$ was rejected and accepted $\mathrm{H}_{1}$, implying that the variables of learning methods, prior ability, and the effect of learning methods and prior ability simultaneously significantly affect students' learning outcomes. Since the model is significant, it is then valid or can be used for further discussion. A full discussion regarding each hypothesis is provided in the next chapters.

1) The difference in investigation multiliteracy and conventional methods towards students' learning outcomes (Hypothesis I)

Tested statistical hypotheses:

$$
\begin{array}{lll}
\mathrm{H}_{0}: \mu \mathrm{A}_{1} & =\mu \mathrm{A}_{2} \\
\mathrm{H}_{1}: \mu \mathrm{A}_{1} & \neq \mu \mathrm{A}_{2}
\end{array}
$$

Where:

$\mathrm{H}_{0} \quad=$ no effect of multiliteracy and conventional methods on students' learning outcomes

$\mathrm{H}_{1} \quad$ = there is an effect of multiliteracy and conventional methods on students' learning outcomes

Table 6 displays that the learning methods simultaneously give a significant effect, as seen in the p-value in the learning methods variable measuring at 0.04 or less than $\alpha=5 \%$. Thus, $\mathrm{H}_{0}$ was rejected and accepted $\mathrm{H}_{1}$, indicating that the variable of learning methods significantly influences students' learning outcomes. In short, there is a difference in multiliteracy and conventional methods towards students' learning outcomes

2) The Effect of Investigation Multiliteracy Method and Students' Prior Ability on Students' Learning Outcomes (Hypothesis III)

The tested hypotheses were as follows.

$H_{0}: \mu A_{1} B_{1}=A_{1} B_{2}=\mu A_{2} B_{1}=\mu A_{2} B_{2}$

$H_{1}: \mu A_{1} B_{1} \neq \mu A_{1} B_{2} \neq \mu A_{2} B_{1} \neq \mu A_{2} B_{2}$

Where:

$\mathrm{H}_{0} \quad=$ no effect of investigation multiliteracy and students' prior ability on learning outcomes of constructing explanatory texts

$\mathrm{H}_{1} \quad=$ there is an effect of investigation multiliteracy and students' prior ability on learning outcomes of constructing explanatory texts

By referring to Table 4.12, it is shown that the $p$-value in the investigation multiliteracy method and prior ability is $0.007<\alpha=$ $5 \%$. Accordingly, $\mathrm{H}_{0}$ was rejected and accepted $\mathrm{H}_{1}$, meaning that the investigation multiliteracy method and prior ability 
significantly affect students' learning outcomes. To sum up, investigation multiliteracy method and prior ability influence students' learning outcomes in constructing explanatory texts.

\section{Results}

3.1. The Difference in Students Learning Outcomes Taught by Investigation Multiliteracy Method (IMM) and Conventional Method (CM)

\subsubsection{Learning Outcomes of Constructing Explanatory Texts with IMM}

A descriptive analysis of students' learning outcomes using the investigation multiliteracy method based on post-test results can be seen in Table 7.

Table 7. Learning Outcomes of Constructing Explanatory Texts with IMM

\begin{tabular}{cc}
\hline Statistics & $\begin{array}{c}\text { Learning Outcomes } \\
\text { with IMM }\end{array}$ \\
\hline $\mathrm{N}$ & 21 \\
Mean & 79 \\
Median & 79 \\
Variance & 67.2 \\
Std. Deviation & 8.19 \\
Range & 24 \\
Minimum Score & 67 \\
Maximum Score & 91 \\
\hline
\end{tabular}

The previous table shows the learning outcomes of 21 students taught by the investigation multiliteracy method with an average score (mean) and a median of 79. Moreover, the variance and standard deviation arrive at 67.2 and 8.19 , respectively. In terms of maximum and minimum scores of learning outcomes through the investigation multiliteracy method, they get 91 and 67 each.

\subsubsection{Learning Outcomes of Constructing Explanatory Texts with CM}

A descriptive analysis of students' learning outcomes relying on the conventional method based on post-test results can be seen in Table 8.

Table 8. Learning Outcomes of Constructing Explanatory Texts with CM

\begin{tabular}{ccc}
\hline Statistics & $\begin{array}{c}\text { Learning Outcomes } \\
\text { with Conventional Method }\end{array}$ & $\begin{array}{c}\text { Learning Outcomes } \\
\text { with IMM }\end{array}$ \\
\hline $\mathrm{N}$ & 21 & \\
Mean & 62.81 & \\
Median & 63 \\
Variance & 167.76 \\
Std. Deviation & 12.95 \\
Range & 58 \\
Minimum Score & 33 \\
Maximum Score & 91 \\
\hline
\end{tabular}

The above table informs the learning outcomes of 21 students taught by the conventional method with an average score (mean) of 62.81 and a median of 63. Further, the variance and standard deviation measure at 167.76 and 12.95 sequentially. In terms of maximum and minimum scores of learning outcomes through a conventional method, they reach 91 and 33 each.

\subsection{The Difference in Learning Outcomes of Constructing Explanatory Texts with IMM and CM}

The following table presents a descriptive analysis of students' learning outcomes using the investigation multiliteracy and conventional method based on post-test results.

Table 9. The Difference in Learning Outcomes with IMM and CM

\begin{tabular}{ccc}
\hline Statistics & \multicolumn{2}{c}{ Learning Outcomes } \\
\cline { 2 - 3 } & IMM & CM \\
\hline $\mathrm{N}$ & 21 & 21
\end{tabular}




$\begin{array}{ccc}\text { Mean } & 79 & 62.81 \\ \text { Median } & 79 & 63 \\ \text { Variance } & 67.2 & 167.76 \\ \text { Std. Deviation } & 8.19 & 12.95 \\ \text { Range } & 24 & 58 \\ \text { Minimum Score } & 67 & 33 \\ \text { Maximum Score } & 91 & 91\end{array}$

Table 9 illustrates that the average score of students studying with the investigation multiliteracy method is 79 , higher than that of students taught by the conventional method with an average score of 62.81. This is evident by the median (79) and minimum score (79) of students taught by the investigation multiliteracy method that are higher than those of students learning with a conventional method (63). The maximum score of students who learn employing both methods is 91 ; the variance and standard deviation achieve 167.76 and 12.95 higher than those of students taught by investigation multiliteracy method with 67.2 (variance) and 8.19 (standard deviation). This signifies that a class using a conventional method is more varied compared to the class with the investigation multiliteracy method. The following Figure 1 visualizes the learning outcomes based on learning methods.

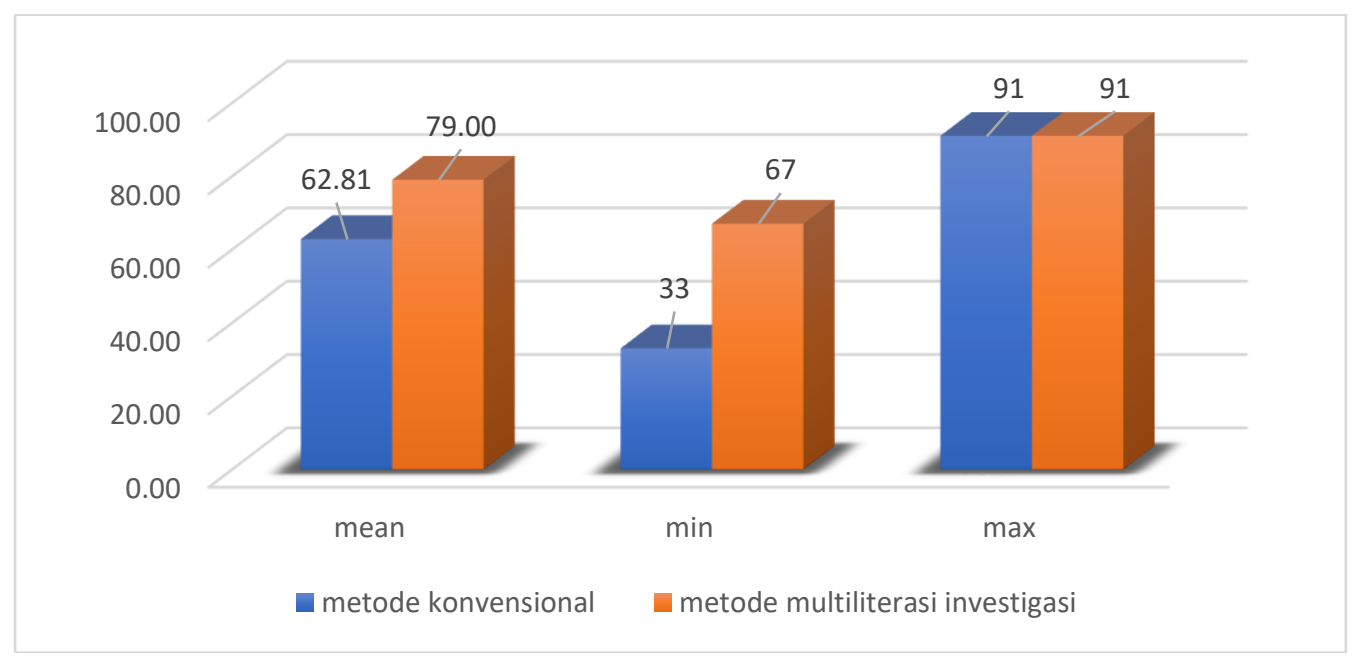

Figure 1. The Learning Outcomes Based on Learning Methods

Description:

Metode Konvensional: Conventional Method

Metode Multiliterasi Investigasi: Investigation Multiliteracy Method

\subsection{The Difference in Learning Outcomes through Investigation Multiliteracy Method (IMM) and Conventional Method} (CM) among Students with High and Low Prior Ability

3.3.1. Learning Outcomes with IMM and CM for High Prior Ability

A descriptive analysis of students' learning outcomes that is grouped based on high prior ability is given in Table 10 and 11.

Table 10. Learning Outcomes with IMM and High Prior Ability

\begin{tabular}{cc}
\hline Statistics & $\begin{array}{c}\text { Learning Outcomes } \\
\text { High Prior Ability }\end{array}$ \\
\hline $\mathrm{N}$ & 5 \\
Mean & 78 \\
Median & 75 \\
Variance & 45 \\
Std. Deviation & 6.71 \\
Range & 15 \\
Minimum Score & 75 \\
Maximum Score & 90
\end{tabular}


The previous table reveals that five out of 21 students have a high prior ability with a mean of 78 and a median of 75 as the learning outcomes. Additionally, the variance and standard deviation get 45 and 6.71, respectively. Those five students reach 90 and 75 each in maximum and minimum scores.

Table 11. Students' Learning Outcomes with CM and High Prior Ability

\begin{tabular}{cc}
\hline Statistics & $\begin{array}{c}\text { Learning Outcomes } \\
\text { High Prior Ability }\end{array}$ \\
\hline $\mathrm{N}$ & 3 \\
Mean & 75 \\
Median & 75 \\
Variance & 0 \\
Std. Deviation & 0 \\
Range & 0 \\
Minimum Score & 75 \\
Maximum Score & 75 \\
\hline
\end{tabular}

The above table presents that three out of 21 students have a high prior ability with both mean and median of 75 . Meanwhile both variance and standard deviation also get 0 . Those three students score 75 as the maximum and minimum score.

\subsubsection{Learning Outcomes with IMM and CM for Low Prior Ability}

A descriptive analysis of students' learning outcomes based on low prior ability is presented in Tables 12 and 13.

Table 12. Learning Outcomes with IMM and Low Prior Ability

\begin{tabular}{cc}
\hline Statistics & $\begin{array}{c}\text { Learning Outcomes } \\
\text { Low Prior Ability }\end{array}$ \\
\hline $\mathrm{N}$ & 16 \\
Mean & 52.81 \\
Median & 55 \\
Variance & 189.89 \\
Std. Deviation & 13.78 \\
Range & 45 \\
Minimum Score & 25 \\
Maximum Score & 70 \\
\hline
\end{tabular}

The above table informs that 16 out of 21 students have the low prior ability with a mean of 52.81 and a median of 55 as the learning outcomes. Besides, the variance and standard deviation measure at 189.89 and 13.78 sequentially. In terms of maximum and minimum score, those 16 students reach 25 and 70 each.

Table 13. Students' Learning Outcomes with CM and Low Prior Ability

\begin{tabular}{cc}
\hline Statistics & $\begin{array}{c}\text { Learning Outcomes } \\
\text { Low Prior Ability }\end{array}$ \\
\hline $\mathrm{N}$ & 18 \\
Mean & 46.94 \\
Vedian & 50 \\
Std. Deviance & 229.82 \\
Range & 15.15 \\
Minimum Score & 60 \\
Maximum Score & 10 \\
\end{tabular}


Table 13 shows that 18 out of 21 students have the low prior ability with a mean of 46.94 and a median of 50 as the learning outcomes. Moreover, the variance and standard deviation account for 229.82 and 15.15, respectively. In terms of maximum and minimum score, those 18 students reach 10 and 70 each.

\subsection{The Difference in Learning Outcomes of Students Learning with IMM and CM and Having High and Low Prior Ability}

A descriptive analysis of students' learning outcomes grouped based on high and low prior ability is provided in Table 14.

Table 14. Difference in Learning Outcomes of Students Taught by IMM and CM with High and Low Prior Ability

\begin{tabular}{cccc}
\hline Learning & \multirow{2}{*}{ Statistics } & \multicolumn{2}{c}{ Prior Ability } \\
\cline { 3 - 4 } & & High & Low \\
\hline Investigation & $\mathrm{N}$ & 5 & 16 \\
Multiliteracy & Mean & 78 & 52.81 \\
(A1) & Std. & 6.71 & 13.78 \\
& Deviation & & \\
\hline Conventional & $\mathrm{N}$ & 3 & 18 \\
(A2) & Mean & 75 & 46.94 \\
& Std. & 0 & 15.15 \\
\hline
\end{tabular}

The above table shows that students with the high prior ability and taught by the investigation multiliteracy method get higher learning outcomes than those taught by the conventional method. Likewise, students with the low prior ability and taught by the investigation multiliteracy method have higher learning outcomes compared to those taught by the conventional method. This is proven by:

a. The mean of students' learning outcomes with the high prior ability and taught by investigation multiliteracy and conventional methods is 78 and 75 , respectively.

b. The mean of students' learning outcomes with the low prior ability and taught by investigation multiliteracy and conventional methods is 52.81 and 46.94 each.

To sum up, students with high and low prior abilities taught by the investigation multiliteracy method get higher learning outcomes than those learned using a conventional method. The detail of learning outcomes based on prior ability is provided in the following Figure 2.

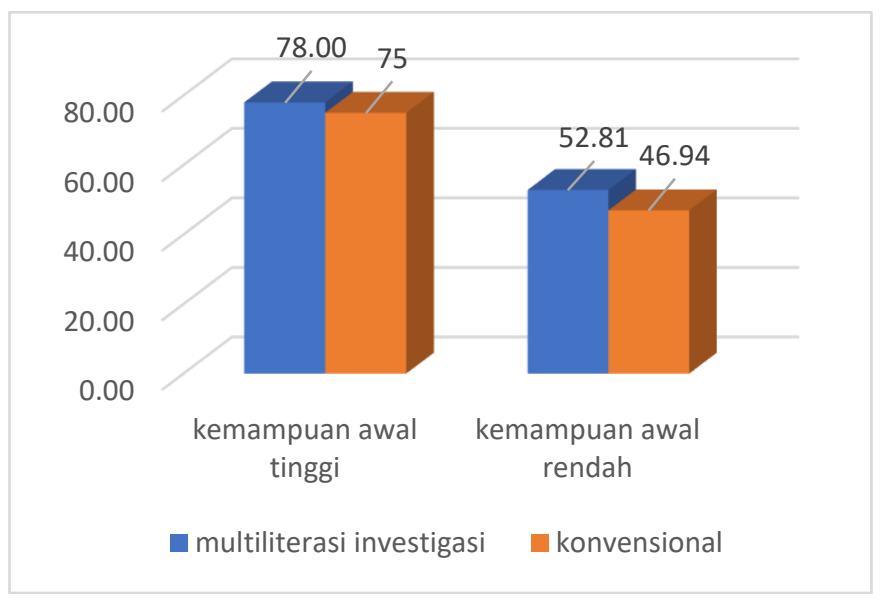

Figure 2. The Detail of Learning Outcomes Based on Prior Ability

Description:

Metode Konvensional

Metode Multiliterasi Investigasi

Kemampuan Awal Tinggi

Kemampuan Awal Rendah
: Conventional Method

: Investigation Multiliteracy Method

: High Prior Ability

: Low Prior Ability 


\subsection{The Effect of Investigation Multiliteracy Method and Prior Ability on Learning Outcomes of Constructing Explanatory Texts among Eleventh-Grade Students}

A descriptive analysis of students' learning outcomes grouped based on learning methods and prior ability is shown in Table 15.

Table 15. The Effect of Investigation Multiliteracy Method and Prior Ability on Students' Learning Outcomes of Constructing

\begin{tabular}{|c|c|c|c|c|c|}
\hline \multirow{3}{*}{$\begin{array}{l}\text { Learning } \\
\text { Method }\end{array}$} & \multirow{3}{*}{ Statistics } & \multicolumn{4}{|c|}{ Prior Ability } \\
\hline & & \multicolumn{2}{|c|}{ High } & \multicolumn{2}{|c|}{ Low } \\
\hline & & $\begin{array}{l}\text { Pre- } \\
\text { test }\end{array}$ & $\begin{array}{l}\text { Post- } \\
\text { test }\end{array}$ & $\begin{array}{l}\text { Pre- } \\
\text { test }\end{array}$ & $\begin{array}{l}\text { Post- } \\
\text { test }\end{array}$ \\
\hline \multirow{5}{*}{ IMM } & $\mathrm{N}$ & 5 & 5 & 16 & 16 \\
\hline & Mean & 78 & 73,40 & 60,16 & 85,08 \\
\hline & Minimum & 75 & 67 & 25 & 67 \\
\hline & Maximum & 90 & 83 & 70 & 91 \\
\hline & $\begin{array}{l}\text { Std. } \\
\text { Deviation }\end{array}$ & 6.71 & 6.07 & 13.78 & 8,13 \\
\hline
\end{tabular}

The above table indicates that only five students have high prior ability, with the mean of pre- and post-test arrives at 78 and 73.40, respectively. On the other hand, there are 16 students with low prior ability, in which the mean of the pre-test is 60.16 , and the mean of the post-test gets 85.08 . The mean score of students with the high prior ability and taught by the investigation multiliteracy method have gone down from 78 in the pre-test to 73.40 in the post-test. Similarly, their minimum and maximum scores in the pre-test also get lower from 75 to 67 and from 90 to 83, consecutively. This gives the idea that the investigation multiliteracy method is not able to improve the learning outcomes of students with high prior ability.

In contrast, those with the low prior ability and taught by the method mentioned above get a quite significant increase in mean scores from 60.16 in the pre-test to 85.08 in the post-test. Likewise, their minimum and maximum scores in the pre-test also get higher from 25 to 67 and from 70 (pre-test) to 83 (post-test), respectively. This brings out that the investigation multiliteracy method can increase students' learning outcomes with the low prior ability.

All in all, the investigation multiliteracy method is able to better students' learning outcomes. The detail of learning outcomes based on the investigation multiliteracy method and prior ability is visualized in the following Figure 3.

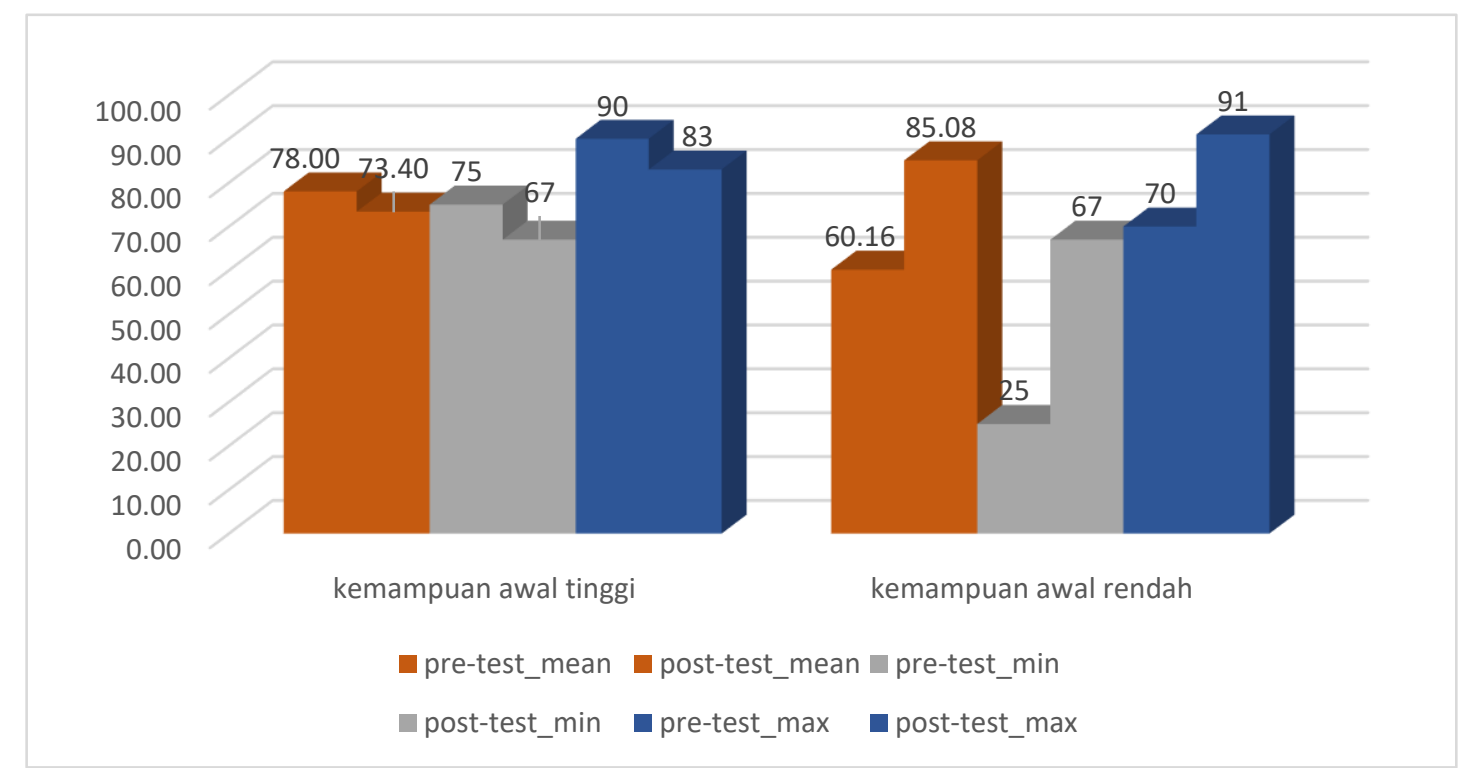

Figure 3. The Detail of Learning Outcomes Based on the Investigation Multiliteracy Method and Prior Ability 


\section{Description:}

Kemampuan Awal Tinggi: High Prior Ability

Kemampuan Awal Rendah: Low Prior Ability

\section{Discussion}

The investigation multiliteracy method can facilitate, master, and develop the scientific process, concept, and attitude being learned. McKee and Ogle (as cited in Abidin, 2015) note that multiliteracy learning can enhance thinking ability in criticizing, analyzing, and evaluating information from different sources in any disciplines and communicating it. Students are given opportunities to discover observation results during the application of the multiliteracy method so that the results will last longer and be unforgettable.

On the contrary, the conventional method is a lecture way of teaching, in which the teacher is more active than the students. The teacher dominates the learning process, from explaining materials to providing sample problems and answering students' questions. Djamarah (2010) opines that conventional or lecture method can be considered traditional as it has been used for a long time as a communication tool between teachers and students in the teaching and learning process.

Based on the findings, the average score (mean) of students taught by the investigation multiliteracy method accounted for 79.00. Meanwhile, those using a conventional method reached an average score of 62.81 . In conclusion, the investigation multiliteracy method leads the students to get a higher score than the conventional method. This is in line with Lilik (2018) study revealing that multiliteracy learning significantly influenced students' learning outcomes. In addition, Gina Elvina Soyan states that investigation multiliteracy is able to better the learning process and students' learning outcomes.

\subsection{The Difference in Students' Learning Outcomes Taught by Investigation Multiliteracy Method (IMM) for Students with High and Low Prior Abilities}

Every individual has different learning abilities. Students' prior ability refers to the one possessed by students before participating in the learning process. Such an ability depicts their readiness to absorb the materials delivered by the teacher. Prior ability is crucial for teachers to find out before they start the lesson as it serves as the requisite to take part in the learning process. Teachers, consequently, can design the learning process more effectively.

Drawing upon the findings, there was a difference in the average learning outcomes (78) of students with the high prior ability and taught by the investigation multiliteracy that was higher than those of students taught by a conventional method (75). Meanwhile, students with low prior ability and taught by the investigation multiliteracy method reached an average score of 52.81 , higher than those taught by a conventional method with an average score of 46.94 . Therefore, students with high and low prior abilities taught by the investigation multiliteracy method get higher learning outcomes than those who learned using a conventional method.

\subsection{The Effect of Investigation Multiliteracy Method and Prior Ability on Students' Learning Outcomes of Constructing Explanatory Texts}

The Multiliteracy method can enhance students' ability as it always associates their experience with scientific concepts. By referring to the findings, the $p$-value in the interaction of investigation multiliteracy method and prior ability was 0.007 or less than $\alpha=5 \%$. Accordingly, $\mathrm{H}_{0}$ was rejected and accepted $\mathrm{H}_{1}$, meaning that the investigation multiliteracy method and prior ability significantly affect students' learning outcomes. In other words, the investigation multiliteracy method and prior ability influence students' learning outcomes in constructing explanatory texts. Similarly, Dafit's research discovered that the investigation multiliteracy method had an effect on students' learning outcomes.

\section{Conclusion}

The main purposes of this study are to describe the learning outcomes of constructing explanatory texts among eleventh-grade students taught by investigating the multiliteracy and conventional methods, the difference in learning outcomes of students taught by investigating the multiliteracy and conventional methods for those with a high and low prior ability, and the effect of investigation multiliteracy method and prior ability on learning outcomes in SMA Posigadan state senior high school. From the result, it can be concluded that the average learning outcomes of students taught by the investigation multiliteracy method are higher than those who were taught by the conventional methods, both for high initial ability and low initial ability. The $p$-value evidence this in the interaction of investigation multiliteracy method and prior ability reaches 0.007 or less than $\alpha=5 \%$. Thus, $\mathrm{H}_{0}$ was rejected and accepted $\mathrm{H}_{1}$, implying that the investigation multiliteracy method and prior ability significantly influence students' learning outcomes. All in all, there is an effect of investigation multiliteracy method and prior ability on students' learning outcomes in constructing explanatory texts. 
The findings of this study provide theoretical and practical contributions. Theoretically, the results of this study support and complement the theories associated with previous learning models/methods, and practically can be used as a reference for educators to choose learning methods that are in accordance with the characteristics of the teaching material. This research is only limited to the effect of this method on student learning outcomes in constructing explanatory text. Therefore it is suggested that further researchers be able to study it in other aspects.

Funding: This research received no external funding.

Acknowledgements: The authors would like to express their gratitude to all parties that have been involved in this research, especially to SMA Posigadan State Senior High School.

Conflicts of Interest: The authors declare no conflict of interest.

\section{References .}

[1] Abidin, Y. (2014). Desain sistem pembelajaran dalam konteks Kurikulum 2013 [Learning System Design in the Context of Curriculum 2013]. Refika Aditama.

[2] Abidin, Y. (2018). Pembelajaran multiliterasi [Multiliteracy learning]. PT Refika Aditama.

[3] Arifin, Z. (2011). Evaluasi pembelajaran [Learning evaluation]. PT Remaja Roesdakarya.

[4] Arikunto, S. (2002). Metodologi penelitian Suatu pendekatan proposal [Research methodology: A proposal approach]. Rineka Cipta.

[5] Arikunto, S. (2014). Prosedur penelitian: Suatu pendekatan praktik [Research procedure: A practical approach]. Rineka Cipta.

[6] Asyar, R. (2012). Kreatif mengembangkan media pembelajaran [Being creative in developing learning media]. Gaung Persada Pers.

[7] Azizah, I. N., Abidin, Y., \& Yunansah, H. (2015). Penggunaan model multiliterasi untuk meningkatkan kemampuan menulis karangan eksposisi (Penelitian tindakan kelas pada siswa kelas V SD Negeri Bima Kecamatan Kesambi Kota Cirebon) [Using Multiliteracy Method to Improve the Ability to Write Expository Essays (Classroom Action Research among Fifth-Grade Students of SD Bima State Elementary School in Kesambi District, Cirebon)]. Antologi, 3(2), 1-10.

[8] Basuki, W., \& Farida, M. (2001). Media pengajaran [Teaching media]. CV Maulana.

[9] Depdiknas. (2003). Kamus besar bahasa Indonesia [Indonesian language dictionary] (3rd ed.). Balai Pustaka.

[10] Dimyati, \& Mudjiono. (2009). Belajar dan pembelajarn [Teaching and learning]. Rineka Cipta.

[11] Djamarah, \& Syaiful, B. Strategi belajar mengajar [Teaching and learning strategies]. Asdi Mahasatya.

[12] Harjanto. (2006). Perencanaan pembelajaran [Lesson planning]. Rineka Cipta

[13] Kosasi, E. (2014). Jenis-jenis teks dalam mata pelajaran bahasa Indonesia SMA/MA/SMK [Types of texts in Indonesian language subject in senior/vocational/islamic high schools]. YramaWidya.

[14] Mahsun. (2014). Teks dalam pembelajaran bahasa Indonesia [Texts in Indonesian Language Learning]. PT Raja Grafindo Persada.

[15] Meldiana, M. (2017). Pembelajaran Mengonstruksi informasi dalam teks eksplanasi dengan menggunakan model mind mapping pada siswa kelas XI SMAN 1 Parongpong [Lesson of constructing information in explanatory texts by applying mind-mapping model among eleventhgrade students of SMA 1 State Senior High School in Parongpong] (Publication No. 30659) [Undergraduate thesis, Universitas Pasundan]. Universitas Pasundan Repository. http://repository.unpas.ac.id/30659/

[16] Mulyadi, Y., \& Andriani. (2014). Bahasa Indonesia untuk kelas XI SMA [Indonesian language for eleventh grade of senior high school]. Yrama Widya.

[17] Muzaini. (2018). Keefetifan pembelajaran multiliterasi dalam meningkatkan motivasi dan hasil belajar siswa Madrasah Ibtidaiyah Imami mata pelajaran fiqih kepanjen Kabupaten Malang [The effectiveness of multiliteracy learning in improving students' motivation and learning outcomes in figh subject at Madrasah Ibtidaiyah Imami Islamic Elementary School in Malang] (Publication No. 12797) [Master thesis, Universitas Islam Negeri Maulana Malik Ibrahim Malang]. UIN Malang Repository. http://etheses.uin-malang.ac.id/12797/

[18] Pardiyono. (2007). Pasti bisa: Teaching genre based writing. Andi Offset.

[19] Restuti. (2013). Mandiri bahasa Indonesia [Sharpening ability: Indonesian language book]. Erlangga

[20] Riduwan. (2013). Skala pengukuran variabel-variabel penelitian [Measurement scale of research variables]. CV Alfabeth.

[21] Rusman. (2012). Model-model pembelajaran: Mengembangkan profesionalisme guru dan kepala sekolah [Learning Models of Developing Teachers' and Principals' Professionalism]. PT Raja Grafindo Persada.

[22] Sadiman, A. S., Rahardjo, R., Haryono, A., \& Harjito. (2008). Media pendidikan: Pengertian, pengembangan, dan pemanfaatannya [Educational media: Definition, development, and utilization]. Rajawali Press.

[23] Slameto. (2003). Belajar dan faktor-faktor yang mempengaruhinnya [Learning and Its Contributing Factors]. Rhineka Cipta.

[24] Sudjana, N., \& Ahmad, R. (2010). Media pengajaran. Sinar Baru.

[25] Sudjana. (2001). Metode statistik. Alfabet.

[26] Sugandi, A. (2000). Teori pembelajaran [Learning theory]. PT Remaja Roesdakarya.

[27] Sugiyono, A. (2014). Metode penelitian pendidikan pendekatan kuantitatif, kualitatif, dan R\&D [Educational research methods with quantitative, qualitative, and R\&D approaches]. Alfabeta.

[28] Suherli, Suryaman, M., Septiaji, A., Istiqomah. (2017). Buku siswa bahasa Indonesia SMA kelas XI K13 [Indonesian high school student books class XI K13]. Pusat Kurikulum dan perbukuan, Balitbang, Kemendibud.

[29] Sukardi, M. (2008). Evaluasi pendidikan prinsip dan operasional [Evaluation of principle and operational education]. Bumi Aksara.

[30] Syah, M. (2006). Psikologi belajar [Learning psychology]. PT Raja Grapindo Persada.

[31] Syamsudin \& Damayanti. (2011). Metode penelitian pendidikan bahasa [Language Education Research Method]. Remaja Rosdakarya.

[32] Triyanto. (2007). Model-model pembelajaran inovatif berorientasi konstruktivisme [Innovative learning models oriented to constructivism]. Prestasi Pustaka. 